Primljen / Received: 19.11.2015. Ispravljen / Corrected: 13.4.2016.

Prihvaćen / Accepted: 25.8.2016. Dostupno online / Available online: 10.3.2017.

\section{Low temperature properties of hot mix asphalts prepared with different polymer modified binders}

Authors:

Preliminary note

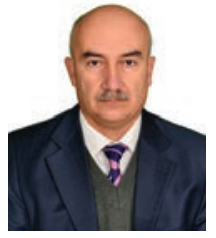

Assoc.Prof. Taner Alataş, PhD. CE

Fırat University, Turkey

Faculty of Engineering

talatas@firat.edu.tr

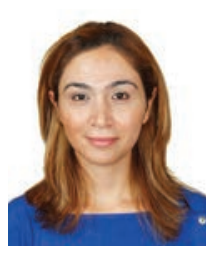

Mesude Yilmaz, PhD. CE

General Directorate of Highways, Turkey myilmaz7@kgm.gov.tr
Taner Alataș, Mesude Yilmaz

Low temperature properties of hot mix asphalts prepared with different polymer modified binders

The low temperature crack propagation resistance of pure and polymer modified mixtures is analysed in the paper by means of linear and nonlinear fracture mechanics. The influence of two bitumen-modification binders is considered: styrene-butadienestyrene (SBS) and ethylene-vinyl-acetate (EVA). The experiments demonstrated that the fracture toughness values increase, and the maximum vertical strain values decrease, with a decrease in temperature. It was established by both techniques used in the paper that the lowest fracture toughness was obtained using the EVA binder.

Key words:

hot mix asphalt, low temperature performance, modification, fracture toughness

Prethodno priopćenje

Taner Alataș, Mesude Yilmaz

Niskotemperaturna svojstva vrućih asfaltnih mješavina s različitim polimerom modificiranim vezivima

U radu se analizira otpornost čistih i polimerima modificiranih mješavina na širenje pukotina pri niskim temperaturama primjenom linearne i nelinearne mehanike loma. Razmatran je utjecaj dva veziva za modificiranje bitumena: stiren-butadien-stiren (SBS) i etilen-vinil-acetat (EVA). Ispitivanja su pokazala da pri padu temperature rastu vrijednosti lomne žilavosti, a smanjuju se vrijednosti maksimalne vertikalne deformacije. Ustanovljeno je da je u oba postupka primijenjena u ovom radu najniža vrijednost lomne žilavosti dobivena primjenom veziva EVA.

Ključne riječi:

vruća asfaltna mješavina, ponašanje pri niskoj temperaturi, modifikacija, lomna žilavost

Vorherige Mitteilung

Taner Alataș, Mesude Yilmaz

Eigenschaften heißer Asphaltmischungen mit verschiedenen durch Polymere modifizierten Bindemitteln bei tiefen Temperaturen

In dieser Arbeit wird mittels linearer und nichtlinearer Bruchmechanik der Widerstand reiner und mit Polymeren modifizierter Mischungen in Bezug auf die Rissausbreitung bei tiefen Temperaturen analysiert. Es wurden die Einflüsse von zwei Bundemitteln zur Modifikation des Bitumens betrachtet: Styrol-Butadien-Styrol (SBS) und EthylenVinylacetat (EVA). Die Untersuchungen haben gezeigt, dass bei einem Temperaturabfall die Werte der Bruchzähigkeit ansteigen und die Werte der maximalen vertikalen Verformungen sinken. Es wurde festgestellt, dass für beide eingesetzte Verfahren die tiefste Bruchzähigkeit bei der Verwendung des Bindemittels EVA auftritt.

Schlüsselwörter:

heiße Asphaltmischung, Verhalten bei tiefen Temperaturen, Modifikation, Bruchzähigkeit 


\section{Introduction}

Many pavement distresses, described as rutting, moistureinduced damage, low temperature cracking etc., may appear on asphalt pavements that have been in use for an extended period of time. Thermal fatigue cracking is one of the major failure modes for asphalt pavements that are subjected to alternating heating and cooling, while low-temperature cracking is a serious distress mode in very cold regions [1-3]. Failure by low temperature cracking occurs as a result of thermal stress buildup in the pavement. Microcracks appear on the surface of the pavement in cases when this stress becomes equal to or greater than the tensile strength of pavement. Propagation of cracks through the pavement is likely to occur as a result of continuing low temperature cycles [4]. When water fills these cracks during winter, it freezes and ice lenses as well as frost heave may develop. This condition results in the loss of fines and formation of voids under the pavement, leading to reduction in load bearing capacity of the pavement. It is important to take appropriate measures during design of pavements to be used in cold regions. Otherwise cracking may cause very serious problems, such as poor ride quality, reduced service life, and high maintenance costs [5].

Polymeric materials can be used as modifiers in bitumen and hot mix asphalt (HMA) mixtures so that a wider performance range can be achieved [6-8]. When plastomers are incorporated into bitumen, the resultant structure is a rigid three dimensional network that resists deformation. However, structures with elastomeric features, i.e., those resisting permanent deformation and recovering the original shape after loading, are obtained by using elastomeric modifiers in bitumen [9]. Styrene-butadiene-styrene (SBS) and ethylene-vinyl-acetate (EVA) are two materials that are most frequently used for bitumen-modification purposes [10]. EVA has been revealed to be a good modifier that improves resistance to permanent deformation and thermal cracking of HMAs [11, 12]. EVA is a copolymer consisting of 5 to 50 wt. \% of vinyl acetate (VA). Acetate groups in the ethylene chain decrease the crystallinity of the copolymer whose properties are controlled by the amount of VA present in the structure. As the VA content increases, the increase in flexibility accompanies the decrease in crystallinity of the copolymer. A flexible copolymer exhibits low melting points and heat seal temperatures, as well as reduced stiffness, tensile strength and hardness [13]. SBS, a copolymer of styrene and butadiene, has a rubbery structure with a three dimensional network of physical cross-links. In the copolymer, while polystyrene (PS) blocks impart strength to the resin, soft polybutadiene (PB) blocks provide elasticity [14].

The structure of PB block in the SBS copolymer can be adjusted by means of special catalysts. This involves partial transfer of the double bonds on the PB blocks to the side chains. It was found that this modification has many advantages for the PMBs, such as low viscosity and better compatibility at equivalent molecular weight, resistance to oxidation, and thermal stability [15, 16].
According to the loading conditions, i.e., speed and temperature, fracture mechanics is used to study the fracture mechanism of hot mix asphalts. Principles of linear-elastic fracture mechanics (LEFM) are applicable to HMAs for the temperatures of $1{ }^{\circ} \mathrm{C}$ or less, while elastic-plastic fracture mechanics (EPFM) principles are applied at convenient loading speeds for the temperatures of $25^{\circ} \mathrm{C}$ and above [17]. Fracture toughness is the ability of a material with a crack to resist fracture. When a stress intensity factor $\left(K_{1}\right)$ exceeds fracture toughness $\left(K_{1 C}\right)$, fracture occurs according to LEFM principles. It is obvious that in order to meet requirements for a satisfactory service life, asphalt pavements should have high fracture toughness values so that they can withstand loads when exposed to an extended range of temperatures. Formation of localized asphalt damage can be observed when the temperature drops under a certain level. This condition, along with the change in the micro-structural stress mechanism, determines the fracture resistance behaviour of asphalt concrete with respect to temperature [18]. However, experimental studies revealed that LEFM is not valid for quasi-brittle materials such as concrete, rock and asphalt concrete because $K_{\mathrm{kc}}$ depends on the size and geometry. The inapplicability of LEFM is due to existence of an inelastic zone, the fracture process zone (FPZ), in front of a crack in quasi-brittle materials. Several non-linear fracture mechanics models have been developed to characterize the FPZ. These models can be classified as the cohesive crack models and the effective crack models. Cohesive crack models simulate the FPZ by a closing pressure, which diminishes near the crack tip, while effective crack models simulate the FPZ by an effective crack length. The main aim of any approach is to determine the critical crack extension (size of FPZ) at peak load.

A long term cyclic fracture, due to cycling loading or change in temperature, and short term cyclic fracture, due to an abrupt drop of temperature along with contraction stresses, are two typical fracture models. Present study mainly deals with the short term cyclic fracture which is a one time fracture failure problem. The crack propagation resistance of pure and polymer modified mixtures is examined in this study by means of two different experimental techniques, and in accordance with the both LEFM and non-linear elastic fracture mechanics, as considered in the above discussion.

\section{Experimental studies}

\subsection{Materials and sample preparation}

The materials used in the experimental study were PG 58-34 bituminous binder, supplied by TUPRAS Batman Refinery; two SBS modifiers, i.e., Kraton D 1101 and Kraton MD 243, produced by Shell Chemical Co.; and Evatane ${ }^{\circledR 2805}$, a type of EVA modifier, produced by Arkema. For the production of modified bitumens, pure bitumen was mixed with a selected modifier for 60 minutes at $180^{\circ} \mathrm{C}$. The speed of the mixer was fixed to 1000 rpm throughout the mixing operation. 
Malatya, a city in the eastern part of Turkey, was selected in the scope of this study as the area for application of the final binder. After taking traffic and climate conditions of the city into account, PG 70-22 was selected as the desired binder performance grade. The binder and hot mix asphalt design were made in this study according to Superpave method. It was reported in previous studies that 3-7\% SBS or 2-6 $\%$ EVA could be added to pure bitumen so that the permanent polymer phase can be obtained [19]. In order to compare the effects of additives on the HMA properties, and based on the information given in literature, the amount of additive was kept constant at $4 \mathrm{wt}$ \% in all mixtures.

Table 1 shows results of the dynamic shear rheometer (DSR) and bending beam rheometer (BBR) tests for pure bitumen as well as mixtures modified with $4 \%$ SBS D1101 (MB SBS-D $\left._{1}\right)$, SBS MD243 (MB SBS-M $)$ and Evatane 2805 $\left(\mathrm{MB}_{\mathrm{EVA}}\right)$. As can be seen in the table, performance grades of $\mathrm{MB}_{\mathrm{SBS}-\mathrm{D}}$ and $\mathrm{MB}_{\text {SBS-M }}$ are the same, i.e., PG 7034. However, the low temperature performance grade of mixture with $\mathrm{MB}_{\mathrm{EVA}}$ was one level lower, namely PG 70-28. Thus, it can be stated that the performances of $M B_{S B S-D}$ and $\mathrm{MB}_{\mathrm{SBS}-\mathrm{M}}$ are better than $\mathrm{MB}_{\mathrm{EVA}}$ at low temperatures. It should be noted that all modified bitumens comply with the desired binder performance grade, PG 70-22.

In order to determine the mixing and compaction temperatures of hot mix asphalts, rotational viscometer tests were also conducted for the unaged pure and modified binders at $135{ }^{\circ} \mathrm{C}$ and $165^{\circ} \mathrm{C}$, respectively. Using the collected viscosity data, a temperature-viscosity graph with the corresponding trend line was drawn to interpret the temperature dependency of the viscosity. The plot was used to determine the mixing and compaction temperatures of the mixtures. According to literature, bitumen binders should possess viscosities of about $170 \pm 20 \mathrm{cP}$ for mixing and $280 \pm$ $30 \mathrm{cP}$ for compaction [20], (Note: 1 centipoise [CP] $=0.001$ pascal second $[\mathrm{Pa} \cdot \mathrm{s}])$. Based on this information and the temperatureviscosity graph, the mixing and compaction temperatures were identified for the corresponding viscosity values. Meanwhile,
Table 1. DSR and BBR test results.

\begin{tabular}{|c|c|c|c|c|}
\hline \multicolumn{5}{|c|}{ DSR test results } \\
\hline \multirow{2}{*}{$\begin{array}{c}\text { Temperature } \\
{\left[{ }^{\circ} \mathrm{C}\right]}\end{array}$} & \multicolumn{4}{|c|}{$\mathrm{G}^{*} / \sin \delta[\mathrm{Pa}]$ (specification limit min. $\left.1000 \mathrm{~Pa}\right)$} \\
\hline & PG 58-34 & $\mathrm{MB}_{\text {SBS-D }}$ & $\mathrm{MB}_{\text {SBS-M }}$ & $\mathrm{MB}_{\mathrm{EVA}}$ \\
\hline 58 & 1258 & 4890 & 4204 & 4534 \\
\hline \multirow[t]{2}{*}{70} & - & 1326 & 1183 & 1512 \\
\hline & \multicolumn{4}{|c|}{$\mathrm{G}^{*} / \sin \delta(\mathrm{Pa}) \mathrm{RTFOT}$ residue (specification limit min. $2200 \mathrm{~Pa}$ ) } \\
\hline 58 & 7862 & - & - & - \\
\hline \multirow[t]{2}{*}{70} & - & 5599 & 5171 & 6862 \\
\hline & \multicolumn{4}{|c|}{$\mathrm{G}^{*} \cdot \sin \delta\left(\mathrm{Pa}^{*} 10^{6}\right) \mathrm{PAV}$ PAV residue (specification limit max. $5 \cdot 10^{6} \mathrm{~Pa}$} \\
\hline 16 & 1.83 & - & - & - \\
\hline 22 & - & 1.69 & 1.52 & - \\
\hline 25 & - & - & - & 1.34 \\
\hline \multicolumn{5}{|c|}{ BBR test results } \\
\hline \multirow{2}{*}{$\begin{array}{l}\text { Temperature } \\
{\left[{ }^{\circ} \mathrm{C}\right]}\end{array}$} & \multicolumn{4}{|c|}{ m value (specification limit min. 0.300 ) } \\
\hline & PG 58-34 & $\mathrm{MB}_{\text {SBS-D }}$ & $\mathrm{MB}_{\mathrm{SBS}-\mathrm{M}}$ & $\mathrm{MB}_{\mathrm{EVA}}$ \\
\hline-18 & - & - & - & 0.306 \\
\hline-24 & 0.309 & 0.314 & 0.325 & 0.277 \\
\hline \multirow[t]{2}{*}{-30} & 0.266 & 0.221 & 0.291 & - \\
\hline & \multicolumn{4}{|c|}{ Creep stiffness [MPa] (specification limit max. 300 MPa) } \\
\hline-18 & - & - & - & 131.3 \\
\hline-24 & 108.3 & 144.7 & 98.5 & 160.6 \\
\hline \multirow[t]{3}{*}{-30} & 140.9 & 242.6 & 121.9 & - \\
\hline & \multicolumn{4}{|c|}{ Performance grades (PG) } \\
\hline & $58-34$ & $70-34$ & $70-34$ & $70-28$ \\
\hline
\end{tabular}

Table 2. Rotational viscosity test results

\begin{tabular}{|l|c|c|c|c|c|}
\hline Properties & Standard & PG 58-34 & MB $_{\text {SBS-D }}$ & MB $_{\text {SBS-M }}$ & MB $_{\text {EVA }}$ \\
\hline Viscosity $\left(\mathrm{CP}, 135^{\circ} \mathrm{C}\right)$ & ASTM D4402 & 275.0 & 1125.0 & 825.0 & 1250.0 \\
\hline Viscosity $\left(\mathrm{CP}, 165^{\circ} \mathrm{C}\right)$ & ASTM D4402 & 112.5 & 350.0 & 262.5 & 375.0 \\
\hline $\begin{array}{l}\text { Modification index } \\
\left(\eta_{\text {modified }} / \eta_{\text {pure, }} \text { on } 135^{\circ} \mathrm{C}\right)\end{array}$ & - & - & 4.09 & 3.00 & 4.55 \\
\hline $\begin{array}{l}\text { Modification indexs } \\
\left(\eta_{\text {modified }} / \eta_{\text {pure }} \text { on } 165^{\circ} \mathrm{C}\right)\end{array}$ & - & - & 3.11 & 2.33 & 3.33 \\
\hline $\begin{array}{l}\text { Mixing temperature } \\
\text { range }\left[{ }^{\circ} \mathrm{C}\right]\end{array}$ & - & $151-158$ & $171-173$ & $169-171$ & $171-173$ \\
\hline $\begin{array}{l}\text { Compaction temperature } \\
\text { range }\left[{ }^{\circ} \mathrm{C}\right]\end{array}$ & $-129-140$ & $167-169$ & $163-166$ & $167-169$ \\
\hline
\end{tabular}

as can be seen in Table 2, the binder fulfilled the workability requirement stating that the viscosity value at $135{ }^{\circ} \mathrm{C}$ should not exceed 3 Pa.s (3000 CP), and so that workability could be maintained [21]. It should be noted that the viscosity of the binder increased with the use of the binders, in which case the mixing and compaction temperatures also increased. Physical properties of the crushed limestone aggregate used in the mixture are summarized in Table 3; the gradation is presented in Figure 1. 
Table 3. Physical properties of aggregate

\begin{tabular}{|l|c|c|c|c|c|}
\hline Properties & Standard & $\begin{array}{c}\text { Specification } \\
\text { limits }\end{array}$ & Coarse & Fine & Filler \\
\hline $\begin{array}{l}\text { Abrasion loss [\%] } \\
\text { (Los Angeles) }\end{array}$ & ASTM D 131 & Max 30 & 27.8 & - & - \\
\hline $\begin{array}{l}\text { Abrasion loss [\%] } \\
\text { (Micro deval) }\end{array}$ & ASTM D 6928 & Max 15 & 13.6 & - & - \\
\hline $\begin{array}{l}\text { Frost action [\%] } \\
\text { (with } \mathrm{Na}_{2} \mathrm{SO}_{4} \text { ) }\end{array}$ & ASTM C 88 & Max 10 & 5.8 & - & - \\
\hline $\begin{array}{l}\text { Flat and elongated } \\
\text { particles [\%] }\end{array}$ & ASTM D 4791 & Max 10 & 3 & - & - \\
\hline Specific gravity [g/cm $\left.{ }^{3}\right]$ & ASTM C127 & & 2.544 & - & - \\
\hline Specific gravity [g/cm $\left.{ }^{3}\right]$ & ASTM C128 & & - & 2.571 & - \\
\hline Specific gravity [g/cm $\left.{ }^{3}\right]$ & ASTM D854 & & - & 2.675 \\
\hline
\end{tabular}

Table 4. Volumetric properties of pure and polymer modified mixtures

\begin{tabular}{|l|c|c|c|c|c|}
\hline \multirow{2}{*}{ Mixture properties } & \multirow{2}{*}{$\begin{array}{c}\text { Specification } \\
\text { limits }\end{array}$} & \multicolumn{4}{|c|}{ Binder type } \\
\cline { 5 - 6 } & & 4.88 & 5.27 & 5.35 & 5.07 \\
\hline $\begin{array}{l}\text { Optimum binder content } \\
{[\%]}\end{array}$ & 4.0 & 4.04 & 4.09 & 4.09 & 3.99 \\
\hline $\begin{array}{l}\text { Volume of air voids, } \\
\text { Va. [\%] }\end{array}$ & min. 14.0 & 14.61 & 15.39 & 15.50 & 14.86 \\
\hline $\begin{array}{l}\text { Voids in mineral } \\
\text { aggregate, VMA [\%] }\end{array}$ & $65-75$ & 72.37 & 73.42 & 73.63 & 73.13 \\
\hline $\begin{array}{l}\text { Voids filled with asphalt, } \\
\text { VFA [\%] }\end{array}$ & $0.8-1.6$ & 1.07 & 0.98 & 0.97 & 1.02 \\
\hline Dust proportion (DP) & max. 89 & 85.71 & 85.62 & 85.52 & 85.09 \\
\hline \%Gmm@Nini. = 8 [\%] & 96 & 95.96 & 95.91 & 95.91 & 96.01 \\
\hline \%Gmm@Ndes. = 100 [\%] & max. 98 & 97.78 & 96.76 & 97.34 & 97.75 \\
\hline \%Gmm@Ndes. = 160 [\%] & & & & & \\
\hline
\end{tabular}

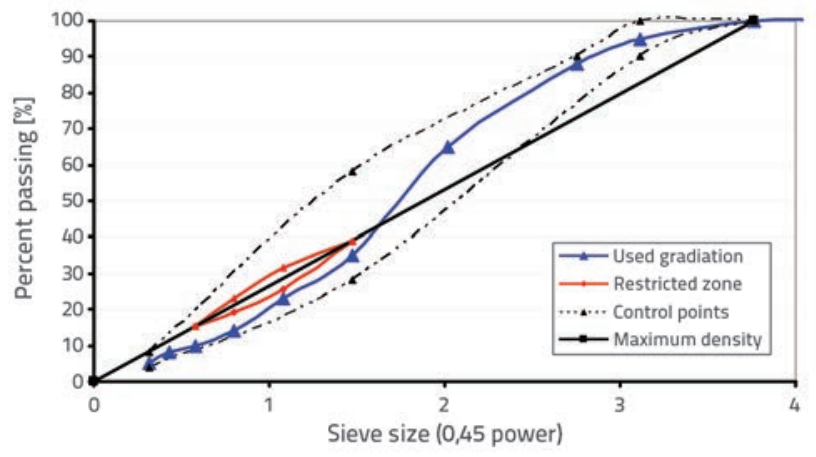

Figure 1. Combined aggregate gradation

In the scope of preparation of the HMAs, bitumen and aggregate were mixed at the mixing temperature $\left(155^{\circ} \mathrm{C}\right.$ for neat mixture, $172{ }^{\circ} \mathrm{C}$ for mixtures prepared with $\mathrm{MB}_{\text {SBS-D }}$ and $\mathrm{MB}_{\text {SBS-D' }}$ and 170
${ }^{\circ} \mathrm{C}$ for mixtures prepared with $\mathrm{MB}_{\mathrm{SBS}-\mathrm{M}}$ ) using a special mixer. Uncompacted samples were placed on plates in an amount of $21-22 \mathrm{~kg} / \mathrm{m}^{2}$. Then, they were placed into an oven preheated to $135{ }^{\circ} \mathrm{C}$, where they were short-term aged for $4 \mathrm{~h}$. After ageing, the samples were compacted at the rate of $30 \mathrm{rpm}$ by gyratory compactor having compaction angle of $1.25^{\circ}$. In the compaction process, vertical compression of $600 \mathrm{kPa}$ was used for 100 rotations. Design binder contents (DBC) of compacted specimens were determined by means of their volumetric properties. As can be seen in Table 4, which shows volumetric properties and Superpave specification limits of the pure and polymer-modified mixtures, DBC values increase with the use of modified binder. The table demonstrates that all mixtures prepared within the scope of the study meet the Superpave specification criteria.

\subsection{Semi-circular bending (SCB) test}

The experimental procedure described in EN 12697-44 was used to measure the resistance of HMA specimens to crack propagation based on the concept of LEFM principles [22]. A gyratory compactor was used for preparation of specimens measuring $150 \mathrm{~mm}$ in diameter and 120 $\mathrm{mm}$ in thickness. Thus, the specimens contained $4 \mathrm{vol}$. \% of air voids at the end of compaction. The compacted specimens were sliced into two equal semi-circular pieces. Then, the resulting semi-circular specimens were cut into two equal slices, each $50 \mathrm{~mm}$ in thickness. A single notch about $10 \mathrm{~mm}$ in depth and $1.5 \mathrm{~mm}$ in width was carved in the middle of the specimens. At the three-point loading configuration, the deformation was performed at the rate of $5.0 \mathrm{~mm} / \mathrm{min}$, see Figure 2 for the loading configuration details.

Three different temperatures, i.e., $0^{\circ} \mathrm{C},-10^{\circ} \mathrm{C}$ and $-20^{\circ} \mathrm{C}$, were selected for the SCB test. Specimens were kept at the test temperature for $6 \mathrm{~h}$ before the testing. The load utilized and the corresponding deformation values were recorded throughout the SCB experiments. The fracture toughness $\left(\mathrm{K}_{\mathrm{IC}}, \mathrm{N} / \mathrm{mm}^{3 / 2}\right)$ and maximum vertical strain values $\left(\varepsilon_{\text {max }^{\prime}} \%\right)$ were calculated using the experimentally determined parameters, i.e., maximum stress value at failure $\left(\sigma_{\text {max }^{\prime}} \mathrm{N} / \mathrm{mm}^{2}\right)$, maximum force value $\left(\mathrm{F}_{\text {max }^{\prime}}\right.$ $N)$, and deformation value at maximum force $(\Delta W, m m)$. For this purpose, the following equations were used: 
$\sigma_{\max }=\frac{4.263^{*} F_{\max }}{D^{*} t}$

$K_{I C}=\sigma_{\max } \cdot 5,956$

$\varepsilon_{\max }=\frac{\Delta W}{W} \cdot 100$

where, $\mathrm{D}, \mathrm{W}$ and $\mathrm{t}$ are the diameter, thickness and height of specimens in $\mathrm{mm}$, respectively. The variation of the fracture toughness $\left(K_{1 C}\right)$ value with the type of additive and temperature is given in Figure 3.
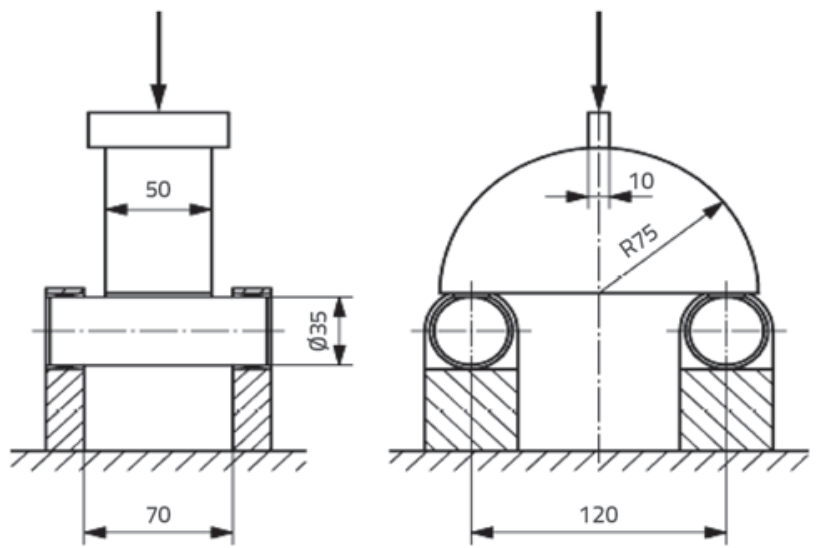

Figure 2. Semi-circular bending test configuration [22]

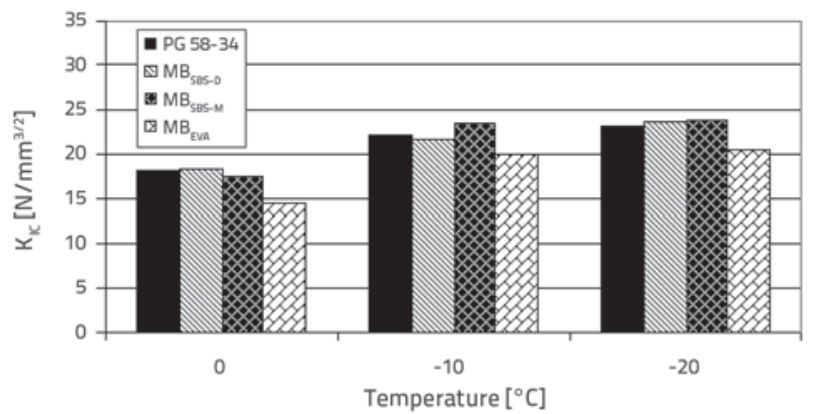

Figure 3. $\mathrm{K}_{\mathrm{IC}}$ values of mixtures obtained by SCB test

As shown in Figure 3, the fracture toughness value increases with a decrease in temperature. At all temperatures, the lowest $\mathrm{K}_{\mathrm{IC}}$ value was obtained in $\mathrm{MB}_{\mathrm{EVA}}$ mixtures. The highest value, on the other hand, was obtained in $\mathrm{MB}_{\mathrm{SBS}-\mathrm{D}}$ at $0^{\circ} \mathrm{C}$ and $\mathrm{MB}_{\mathrm{SBS}-\mathrm{M}}$ at $-10{ }^{\circ} \mathrm{C}$ and $-20^{\circ} \mathrm{C}$. At the temperature of $0{ }^{\circ} \mathrm{C}$, the $\mathrm{K}_{\mathrm{IC}}$ value of the control mixture (prepared with PG 58-34) was by $24.9 \%$ higher than that of $\mathrm{MB}_{\mathrm{EVA}}$. Similarly, at the same temperature, the $\mathrm{K}_{\mathrm{IC}}$ value of the mixture with $\mathrm{MB}_{\mathrm{SBS}-\mathrm{D}}$ was found to be by $26.5 \%$ higher than that of the mixture with $\mathrm{MB}_{\mathrm{EVA}}$ and by 20.9 $\%$ higher than that of mixture with $\mathrm{MB}_{\mathrm{SBS}-\mathrm{M} \text {. At the temperatures }}$ of $-10{ }^{\circ} \mathrm{C}$ and $-20{ }^{\circ} \mathrm{C}$, the mixture with $\mathrm{MB}_{\mathrm{SBS}-\mathrm{M}^{\prime}}$ which had the highest $\mathrm{K}_{\mathrm{IC}}$ value overall, had the $\mathrm{K}_{\mathrm{IC}}$ value by $17.9 \%$ and $15.7 \%$ higher than that of the mixture with $\mathrm{MB}_{\mathrm{EVA}}$, respectively.

It was detected that $\mathrm{K}_{\mathrm{IC}}$ values increase significantly if the temperature drops from $0{ }^{\circ} \mathrm{C}$ to $-10^{\circ} \mathrm{C}$. In such a case, the increase in the $K_{\mathrm{IC}}$ value was $22.9 \%, 18.4 \%, 34.1 \%$ and $37.5 \%$ for the mixture with pure bitumen ( $\mathrm{PG} 58-34$ ), $\mathrm{MB}_{\mathrm{SBS}-\mathrm{D}^{\prime}} \mathrm{MB}_{\mathrm{SBS}-\mathrm{M}}$ and $\mathrm{MB}_{\mathrm{EVA}}$, respectively. However, the increase was less significant when the temperature was changed from $-10{ }^{\circ} \mathrm{C}$ to $-20{ }^{\circ} \mathrm{C}$. This was acquired if the increase in $\mathrm{K}_{\mathrm{IC}}$ value was calculated for temperature drop from $0{ }^{\circ} \mathrm{C}$ to $-20^{\circ} \mathrm{C}$. For this condition, it was detected that the increase was $27.8 \%, 28.7 \%, 35.9 \%$ and $41.9 \%$ for mixture with PG 58-34, $\mathrm{MB}_{\mathrm{SBS}-\mathrm{D}^{\prime}} \mathrm{MB}_{\mathrm{SBS}-\mathrm{M}}$ and $\mathrm{MB}_{\mathrm{EVA}}$ respectively. This also shows that the mixture with $\mathrm{MB}_{\mathrm{EVA}}$ was affected the most by temperature drop. Variations of maximum strain $\left(\varepsilon_{\max }\right)$ values with temperature and the type of additive are given in Figure 4.

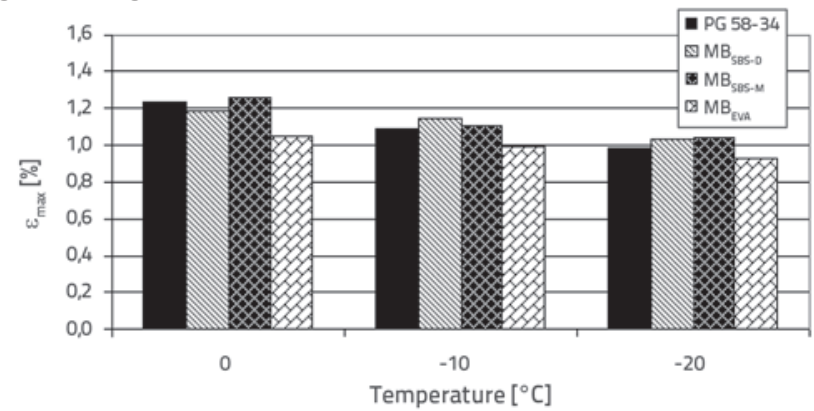

Figure 4. Maximum vertical strain $\left(\varepsilon_{\max }\right)$ values of mixtures

As shown in Figure 4, the mixture with $\mathrm{MB}_{\mathrm{EVA}}$ had the smallest $\varepsilon_{\max }$ value at all temperatures. In contrast to that the highest value was obtained for $\mathrm{MB}_{\mathrm{SBS}-\mathrm{M}}$ at $0{ }^{\circ} \mathrm{C}$ as well as at $-20^{\circ} \mathrm{C}$ and for $\mathrm{MB}_{\mathrm{SBS}-\mathrm{D}}$ at $-10^{\circ} \mathrm{C}$. At the temperatures of $0{ }^{\circ} \mathrm{C}$ and $-20^{\circ} \mathrm{C}$, the $\varepsilon_{\max }$ value of the mixture with $\mathrm{MB}_{\mathrm{SBS}-\mathrm{M}}$ was by $19.8 \%$ and $12.6 \%$ higher than that of mixture with $\mathrm{MB}_{\mathrm{EVA}}$, respectively. It was found that the difference was $14.7 \%$ at $-10{ }^{\circ} \mathrm{C}$.

It was observed that maximum strain values decrease with the decrease in temperature. When the temperature decreased from $0{ }^{\circ} \mathrm{C}$ to $-10{ }^{\circ} \mathrm{C}$, the decrease in $\varepsilon_{\max }$ value was $13.9 \%, 3.5 \%, 14.5$ $\%$ and $5.6 \%$ for the mixture with pure binder, $\mathrm{MB}_{\mathrm{SBS}-\mathrm{D}^{\prime}}, \mathrm{MB}_{\mathrm{SBS}-\mathrm{M}}$ and $\mathrm{MB}_{\mathrm{EVA} A^{\prime}}$ respectively. In case of temperature reduction from $0{ }^{\circ} \mathrm{C}$ to $-20{ }^{\circ} \mathrm{C}$, the decrease in $\mathrm{K}_{\mathrm{IC}}$ value was $25.3 \%, 14.5 \%, 20.6$ $\%$ and $13.4 \%$ for the mixture with pure binder, $\mathrm{MB}_{\mathrm{SBS}-\mathrm{D}^{\prime}} \mathrm{MB}_{\mathrm{SBS}-\mathrm{M}}$ and $\mathrm{MB}_{\mathrm{EVA} A^{\prime}}$ respectively. It can be seen that the $\varepsilon_{\max }$ value of the $\mathrm{MB}_{\mathrm{EVA}}$ mixtures was affected the least from temperature drop, as the $\varepsilon_{\max }$ value of this mixture was rather small at all temperatures.

According to semi-circular bending tests, it can be stated that the mixtures with maximum resistance to crack propagation at $0{ }^{\circ} \mathrm{C}$ would be $\mathrm{MB}_{\mathrm{SBS}-\mathrm{D}^{\prime}}$ while at $-10{ }^{\circ} \mathrm{C}$ and $-20{ }^{\circ} \mathrm{C}$, such mixtures would be $\mathrm{MB}_{\mathrm{SBS}-\mathrm{M}^{*}}$ In contrast to those, the resistance to crack propagation at low temperatures is fairly low for $\mathrm{MB}_{\mathrm{EVA}}$ mixtures. Meanwhile, the experiments pointed out that with the addition of the elastomeric type of additives (Kraton D 1101 and Kraton MD 243), the $\varepsilon_{\max }$ value of the binder can be increased at lower temperatures, while the $\varepsilon_{\max }$ value decreases with the use of plastomeric type of additives (Evatane ${ }^{\circledR}$ 2805). 


\subsection{Single edge notched beam test}

The single-edge notched beam (SE(B)) test geometry has been frequently applied [23, 24] for determining the fracture toughness value of asphalt concrete. Compared to other proposed geometries, this geometry yields more reliable results in the determination of fracture toughness, by providing simple loading configurations, by minimizing the edge effect by large dimensions and stable crack propagation in Mode I [25]. In fact, a standard was not previously set for determining fracture properties of prism shaped asphalt concrete. For this reason, dimensions used by Kim and Hussein (1997) were selected in this study as specimen dimensions [18]. To this end, first slab-shaped specimens measuring $30.5 \times 30.5 \times 5.0 \mathrm{~cm}$ were compacted by roller compactor to 4 vol. $\%$ of air voids. The amount of HMA necessary for slab specimens was calculated using the following equation:

$M=10^{-6} \cdot L \cdot I \cdot e \cdot \rho_{m} \cdot((100-v) / 100)$

where:

$\mathrm{M}$ - the weight of the specimen [kg]

$\mathrm{L} \quad$ - the inner length of the mould [mm]

I - the inner width of the mould [mm]

e - the final height of the specimen [mm]

$\rho_{m}$ - the maximum density of the bituminous mixture $\left[\mathrm{kg} / \mathrm{m}^{3}\right]$

$v \quad$ - the air voids of the specimen [\%].

After the complete cooling of the specimen, it was cut to the required dimensions as given above. First, an insert positioned at the bottom centre of the beam mould was used to form a notch on the specimens having initial notch-depth $\left(a_{0}\right)$ of 21 $\mathrm{mm}$ and initial notch-depth to beam-depth (W) ratio of 0.3. By using the three-point bending configuration, the specimens were deformed at a constant cross-head deformation rate of $3.24 \mathrm{~mm} / \mathrm{min}$. The configuration is shown in Figure 5 . The loading span/notch depth ratio (S/W) of 4 was adopted in all deformation experiments.
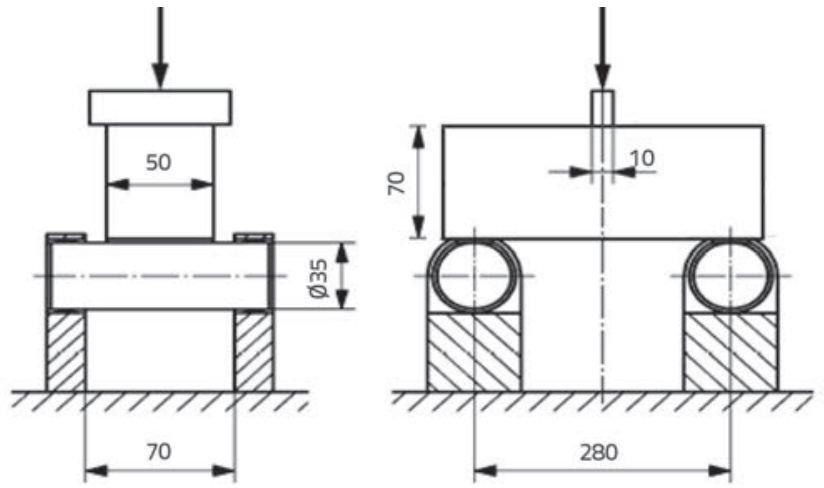

Figure 5. Single edge bending test configuration [18]

The effective crack model (ECM) was applied to determine the fracture behaviour of the specimens. By using $P_{i}$ as $P_{\max } / 2[\mathrm{~N}], \delta$ as deformation at $P_{i}$ [mm]; $B, W$ and $S$ as width, depth and length of specimens [mm]; $w$ as weight per unit length of beam, the Young's modulus $(E)$ of the mixtures was calculated using the following equation [26]:

$$
\begin{aligned}
E & =\frac{P i}{4 B \delta_{i}}\left(\frac{S}{W}\right)^{3}\left[1+\frac{5 w S}{8 P_{i}}+\left(\frac{W}{S}\right)^{2}\left[2,70+1,35 \frac{w S}{P i}\right]-0,84\left(\frac{W}{S}\right)^{3}\right] \\
& +\frac{9 P_{i}}{2 B \delta_{i}}\left(1+\frac{w S}{2 P_{i}}\right)\left(\frac{S}{W}\right)^{2} F_{2}\left(\alpha_{0}\right)
\end{aligned}
$$

Here, the value of $F_{2}\left(\alpha_{0}\right)$ is determined as follows:

$F_{2}\left(\alpha_{0}\right)=\int_{0}^{\alpha_{0}} \beta F_{1}^{2}(\beta) d \beta_{1}$

By using the known values of $\alpha_{0}=a_{0} / W$ and $S / W, F_{1}(\beta)$ can be re-written as

$F_{1}(\beta)=\frac{1,99-\beta(1-\beta)\left(2,15-3,93 \beta+2,70 \beta^{2}\right)}{(1+2 \beta)(1-\beta)^{1.5}}$

process zone ahead of a visible crack are two main reasons for the reduction of beam stiffness. However, as it is rather difficult to distinguish between them, it is assumed that the critical notch depth $(a)$ could be calculated by introducing a fictitious beam containing a notch $a_{e^{\prime}}$. It should be noted that, here, the notch has an unchanged stiffness that would be equal to the reduced stiffness of the real beam containing a notch of depth $a_{\sigma^{\prime}}$ i.e.

$$
\begin{aligned}
\delta_{\max } & =\frac{P_{\max }}{4 B E}\left(\frac{S}{W}\right)^{3}\left[1+\frac{5 w S}{8 P_{\max }}+\left(\frac{W}{S}\right)^{2}\left[2,70+1,35 \frac{w S}{P_{\max }}\right]-0,84\left(\frac{W}{S}\right)^{3}\right] \\
& +\frac{9 P_{\max }}{2 B E}\left(1+\frac{w S}{2 P_{\max }}\right)\left(\frac{S}{W}\right)^{2} F_{2}\left(\alpha_{e}\right)
\end{aligned}
$$

where

$F_{2}\left(\alpha_{e}\right)=\int_{0}^{\alpha_{e}} \beta F_{1}^{2}(\beta) d \beta_{1}$

It should be noted that the values of $\alpha_{e}$ is $a_{e} / W$ and $F_{1}(\beta)$ is directly obtained by using Equation 7. Then, the following equation can be applied to calculate the critical stress intensity factor $\left(\mathrm{K}_{\mathrm{IC}}\right)$ of the specimens;

$K_{l C}=\sigma_{n} \sqrt{a_{e}} F(\alpha)$

where

$\sigma_{n}=\frac{3\left(P_{\max }+w S / 2\right) S}{2 b d^{2}}$

Variations of maximum load values $\left(\mathrm{P}_{\max }\right)$ of the mixtures with the type of additive and temperature are given in Figure 6. As shown in Figure 6, the maximum load value increases with the decrease in temperature. At all temperatures, the lowest value of $P_{\max }$ was obtained in $\mathrm{MB}_{\mathrm{EVA}}$. The highest value, on the other hand, was obtained in the mixture with $\mathrm{MB}_{\mathrm{SBS}-\mathrm{D}}$ at temperatures 
of $0{ }^{\circ} \mathrm{C}$ and $-10{ }^{\circ} \mathrm{C}$. At $-20{ }^{\circ} \mathrm{C}$, the highest value was obtained in the mixture with $\mathrm{MB}_{\mathrm{SBS}-\mathrm{M}}$. It was found that the $\mathrm{P}_{\max }$ value of the mixture with $\mathrm{MB}_{\mathrm{SBS}-\mathrm{D}}$ was by $18.9 \%$ and $15.4 \%$ higher than those with $\mathrm{MB}_{\mathrm{EVA}}$ at $0^{\circ} \mathrm{C}$ and $-10^{\circ} \mathrm{C}$, respectively. At $-20^{\circ} \mathrm{C}$, the highest $P_{\max }$ value, obtained from the mixture with $\mathrm{MB}_{\mathrm{SBS}-\mathrm{M}^{\prime}}$ was by $25 \%$ higher than the lowest $P_{\max }$ value, which was obtained from the mixture with $\mathrm{MB}_{\mathrm{EVA}}$.

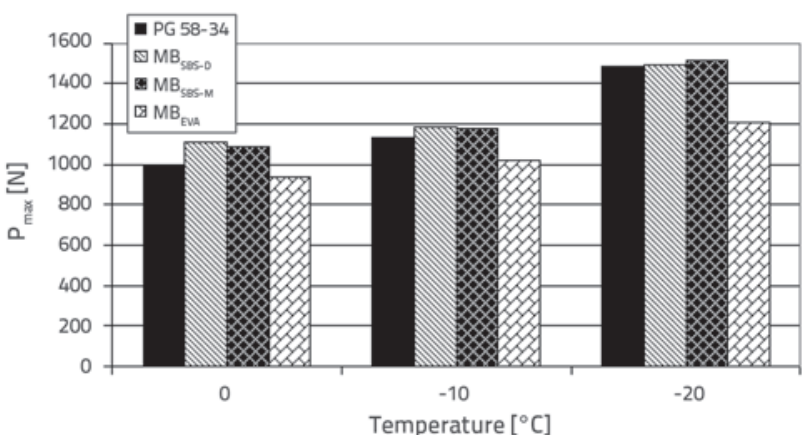

Figure 6. Variation of $P_{\max }$ values with type of additive and temperature

There was a significant increase in the $P_{\max }$ value when the temperature was decreased from $-10{ }^{\circ} \mathrm{C}$ to $-20{ }^{\circ} \mathrm{C}$. In this condition, $\mathrm{P}_{\max }$ values of the mixture with pure binder, $\mathrm{MB}_{\mathrm{SBS}-\mathrm{D}^{\prime}}$ $\mathrm{MB}_{\text {SBS-M }}$ and $\mathrm{MB}_{\mathrm{EVA}}$ increased by $31.2 \%, 26.0 \%, 28.3 \%$ and 17.9 $\%$, respectively. Similarly, when the temperature was decreased from $0{ }^{\circ} \mathrm{C}$ to $-10{ }^{\circ} \mathrm{C}, \mathrm{P}_{\max }$ values of the mixture with pure binder, $\mathrm{MB}_{\mathrm{SBS}-\mathrm{D}^{\prime}} \mathrm{MB}_{\mathrm{SBS}-\mathrm{M}}$ and $\mathrm{MB}_{\mathrm{EVA}^{\prime}}$ increased by $12.6 \%, 6.5 \%, 8.9 \%$ and $9.7 \%$, respectively. These results show that the mixture with pure binder was affected the most by temperature change in terms of $P_{\max }$ value. The variation of deformation $\left(\delta_{\max }\right)$ value at maximum load with temperature is given in Figure 7.

As shown in Figure 7, the highest $\delta_{\max }$ value was obtained in the mixture with $\mathrm{MB}_{\mathrm{SBS}-\mathrm{D}}$ at the temperature of $0{ }^{\circ} \mathrm{C}$. At the temperatures of $-10^{\circ} \mathrm{C}$ and $-20{ }^{\circ} \mathrm{C}$, the highest value was registered for $\mathrm{MB}_{\mathrm{SBS}-\mathrm{D}}$ and $\mathrm{MB}_{\mathrm{SBS}-\mathrm{M}^{\prime}}$ respectively. It was identified that at $-10{ }^{\circ} \mathrm{C}, \delta_{\max }$ values of $\mathrm{MB}_{\mathrm{SBS}-\mathrm{D}}$ and $\mathrm{MB}_{\text {SBS-M }}$ were by 4.0 $\%$ and $3.3 \%$ higher than that of the mixture, respectively. $\delta_{\max }$ values decreased regularly with the decrease in temperature. The variation of fracture toughness values with the type of additive and temperature is given in Figure 8.

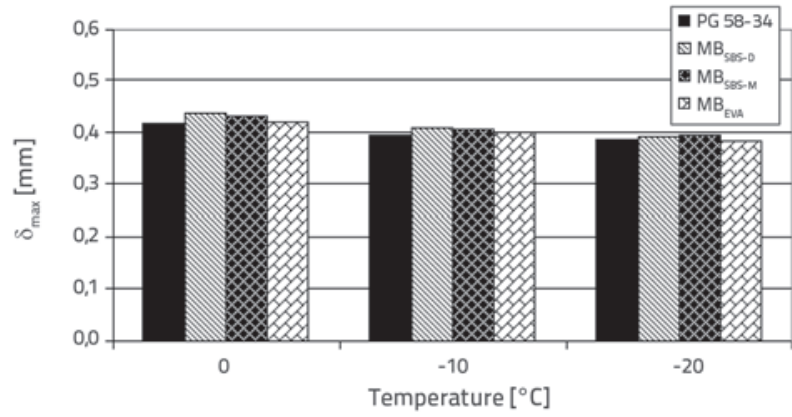

Figure 7. Vertical deformation at maximum load $\left(\delta_{\max }\right)$ values of mixtures

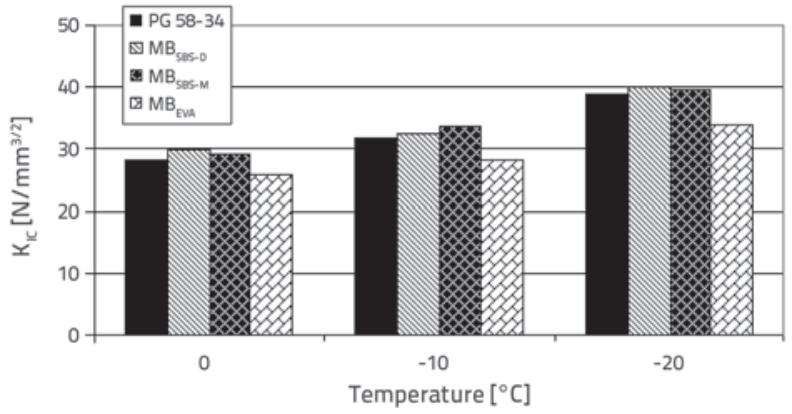

Figure 8. $K_{\mathrm{IC}}$ values of mixtures obtained at single edge bending test

Figure 8 shows that the $\mathrm{K}_{\mathrm{IC}}$ value increases at all temperatures with the use of SBS in mixtures, while it decreases with the use of EVA. At the temperatures of $0{ }^{\circ} \mathrm{C}$ and $-20{ }^{\circ} \mathrm{C}$, the highest value was obtained in $\mathrm{MB}_{\mathrm{SBS}-\mathrm{D}}$. It was found that at $-10{ }^{\circ} \mathrm{C}$, the highest value was obtained for the mixture with $\mathrm{MB}_{\mathrm{SBS}-\mathrm{M}}$. At the temperatures of $0{ }^{\circ} \mathrm{C}$ and $-20{ }^{\circ} \mathrm{C}$, the $\mathrm{K}_{\mathrm{IC}}$ value of the mixture with $\mathrm{MB}_{\mathrm{SBS}-\mathrm{D}}$ was by $15.8 \%$ and $18.6 \%$ higher compared to the one with $\mathrm{MB}_{\mathrm{EVA}}$, respectively. At $-10{ }^{\circ} \mathrm{C}$, the $\mathrm{K}_{\mathrm{IC}}$ value of the mixture with $\mathrm{MB}_{\mathrm{SBS}-\mathrm{M}}$ was by $18.5 \%$ higher compared to the one with $\mathrm{MB}_{\mathrm{EVA}}$, respectively.

$\mathrm{K}_{\mathrm{IC}}$ values increased regularly with the decrease in temperature. When the temperature was decreased from $0{ }^{\circ} \mathrm{C}$ to $-10{ }^{\circ} \mathrm{C}, \mathrm{K}_{\mathrm{IC}}$ values of the mixture with pure binder, $\mathrm{MB}_{\mathrm{SBS}-\mathrm{D}^{\prime}} \mathrm{MB}_{\mathrm{SBS}-\mathrm{M}}$ and $\mathrm{MB}_{\mathrm{EVA}^{\prime}}$ increased by $12.5 \%, 9.1 \%, 14.6 \%$ and $10.0 \%$, respectively. Similarly, when the temperature was decreased from $0{ }^{\circ} \mathrm{C}$ to $-20{ }^{\circ} \mathrm{C}, \mathrm{K}_{\mathrm{lC}}$ values increased by $38.0 \%, 34.8 \%, 35.4 \%$ and 31.6 $\%$, respectively.

\subsection{Comparison of results of fracture mechanics tests}

When compared with Figure 3 based on LEFM and Figure 8 based on the non-linear fracture mechanics, $K_{k c}$ values obtained from beam tests (approximately $30 \mathrm{Nmm}^{3 / 2}$ ) were greater than those of semi-circular bending tests (approximately $20 \mathrm{Nmm}^{3 / 2}$ ). This points to the existence of an inelastic zone (FPZ) in front of a crack in asphalt materials in even lower temperature ranges. The ECM based on nonlinear fracture mechanics can also be employed to determine whether the quasi-brittle material behaviour is ductile or brittle. According to ECM, the relative length of FPZ $\left(\alpha_{e}-\right.$ $\alpha_{0}$ ) gives a good indication of brittleness. For instance, the length of FPZ is zero for perfectly brittle materials and LEFM is applicable.

As shown in Table 5, 6 and 7, the relative effective crack length $\left(\alpha_{\mathrm{e}}\right)$ slightly decreases with the decrease in temperature. Consequently, it may be concluded that the beam specimens exhibit a more brittle behaviour with the decrease in temperature. However, it is well known that the tensile strength of asphalt materials, which is the most important parameter in cohesive crack approaches, increases with 
the decrease in temperature. As clearly indicated in Table 5 and Table 6 , the nominal strength values of beams highly increased with the decrease in temperature. Finally, it was concluded based on this discussion that the critical stress intensity factor values of the beam specimens increase with the decrease in temperature.

Table 5. SE(B) test results at $0^{\circ} \mathrm{C}$

\begin{tabular}{|c|c|c|c|c|c|c|c|c|c|}
\hline \multicolumn{10}{|c|}{$0^{\circ} \mathrm{C}$} \\
\hline Mixture type & Sample No. & $\begin{array}{c}\mathbf{P}_{\mathbf{i}} \\
{[\mathrm{N}]}\end{array}$ & $\begin{array}{c}\delta_{i} \\
{[\%]}\end{array}$ & $\begin{array}{c}\mathbf{E} \\
{\left[\mathrm{N} / \mathrm{mm}^{2}\right]}\end{array}$ & $\begin{array}{l}\mathbf{P}_{\max } \\
{[\mathrm{N}]}\end{array}$ & $\begin{array}{l}\delta_{\text {mak }} \\
{[\%]}\end{array}$ & $\begin{array}{c}\sigma_{\mathrm{Nc}} \\
{[\mathrm{MPa}]}\end{array}$ & $\alpha_{e}$ & $\begin{array}{c}\mathbf{K}_{\mathrm{IC}} \\
{\left[\mathrm{N} / \mathrm{mm}^{3 / 2}\right]}\end{array}$ \\
\hline \multirow{4}{*}{ Neat } & 1 & 506.51 & 0.1027 & 3498 & 1013.01 & 0.4042 & 1.737 & 0.545 & 30.259 \\
\hline & 2 & 476.48 & 0.1174 & 2909 & 952.97 & 0.397 & 1.630 & 0.516 & 25.76 \\
\hline & 3 & 522.39 & 0.1277 & 2878 & 1044.78 & 0.4488 & 1.786 & 0.52 & 28.658 \\
\hline & Mean & & & 3095 & 1003.59 & 0.4167 & & & 28.226 \\
\hline \multirow{4}{*}{$M B_{S B S-D}$} & 1 & 575.44 & 0.1362 & 2927 & 1150.87 & 0.4335 & 1.973 & 0.495 & 29.103 \\
\hline & 2 & 559.7 & 0.1345 & 2897 & 1119.41 & 0.4563 & 1.919 & 0.51 & 29.718 \\
\hline & 3 & 531.83 & 0.1131 & 3297 & 1063.66 & 0.4231 & 1.820 & 0.533 & 30.389 \\
\hline & Mean & & & 3040 & 1111.31 & 0.4376 & & & 29.737 \\
\hline \multirow{4}{*}{$\mathrm{MB}_{\text {SBS-M }}$} & 1 & 547.67 & 0.1181 & 3235 & 1095.34 & 0.4326 & 1.874 & 0.527 & 30.72 \\
\hline & 2 & 523.86 & 0.1294 & 2838 & 1047.72 & 0.4217 & 1.787 & 0.504 & 27.162 \\
\hline & 3 & 551.64 & 0.1291 & 2973 & 1103.29 & 0.4458 & 1.886 & 0.514 & 29.651 \\
\hline & Mean & & & 3015 & 1082.11 & 0.4333 & & & 29.178 \\
\hline \multirow{4}{*}{$\mathrm{MB}_{\mathrm{EVA}}$} & 1 & 425.58 & 0.1261 & 2475 & 851.17 & 0.414 & 1.456 & 0.514 & 22.915 \\
\hline & 2 & 480.49 & 0.1227 & 2806 & 960.98 & 0.4261 & 1.647 & 0.521 & 26.481 \\
\hline & 3 & 496.02 & 0.1172 & 3005 & 992.03 & 0.4169 & 1.696 & 0.525 & 27.621 \\
\hline & Mean & & & 2762 & 934.73 & 0.419 & & & 25.672 \\
\hline
\end{tabular}

Table 6. SE(B) test results at $-10^{\circ} \mathrm{C}$ and $-20^{\circ} \mathrm{C}$

\begin{tabular}{|c|c|c|c|c|c|c|c|c|c|}
\hline \multicolumn{10}{|c|}{$-10^{\circ} \mathrm{C}$} \\
\hline Mixture type & Sample No. & $\begin{array}{c}\mathbf{P}_{\mathrm{i}} \\
{[\mathrm{N}]}\end{array}$ & $\begin{array}{c}\delta_{i} \\
{[\%]}\end{array}$ & $\begin{array}{c}\mathbf{E} \\
{\left[\mathrm{N} / \mathrm{mm}^{2}\right]}\end{array}$ & $\begin{array}{l}\mathbf{P}_{\max } \\
{[\mathrm{N}]}\end{array}$ & $\begin{array}{l}\delta_{\text {mak }} \\
{[\%]}\end{array}$ & $\begin{array}{c}\sigma_{\mathrm{Nx}} \\
{[\mathrm{MPa}]}\end{array}$ & $\alpha_{e}$ & $\begin{array}{c}\mathbf{K}_{\mathrm{IC}} \\
{\left[\mathrm{N} / \mathrm{mm}^{3 / 2}\right]}\end{array}$ \\
\hline \multirow{4}{*}{ Neat } & 1 & 575.05 & 0.1113 & 3566 & 1150.1 & 0.4066 & 1.962 & 0.525 & 31.957 \\
\hline & 2 & 555.5 & 0.0927 & 4180 & 1111 & 0.3785 & 1.905 & 0.549 & 33.646 \\
\hline & 3 & 564.1 & 0.1179 & 3329 & 1128.2 & 0.3947 & 1.934 & 0.507 & 29.66 \\
\hline & Mean & & & 3692 & 1129.77 & 0.3933 & & & 31.755 \\
\hline \multirow{4}{*}{$\mathrm{MB}_{\mathrm{SBS}-\mathrm{D}}$} & 1 & 585.05 & 0.1087 & 3718 & 1170.1 & 0.4061 & 2.006 & 0.529 & 33.066 \\
\hline & 2 & 602.4 & 0.1147 & 3594 & 1204.8 & 0.4196 & 2.055 & 0.524 & 33.305 \\
\hline & 3 & 587.7 & 0.1183 & 3424 & 1175.4 & 0.4015 & 2.011 & 0.508 & 30.974 \\
\hline & Mean & & & 3579 & 1183.43 & 0.4091 & & & 32.448 \\
\hline \multirow{4}{*}{$\mathrm{MB}_{\mathrm{SBS}-\mathrm{M}}$} & 1 & 578 & 0.1016 & 3938 & 1156 & 0.4001 & 1.982 & 0.54 & 33.944 \\
\hline & 2 & 582.45 & 0.1032 & 3902 & 1164.9 & 0.4046 & 1.997 & 0.539 & 34.068 \\
\hline & 3 & 606.8 & 0.1199 & 3475 & 1213.6 & 0.4146 & 2.080 & 0.511 & 32.338 \\
\hline & Mean & & & 3772 & 1178.17 & 0.4064 & & & 33.45 \\
\hline \multirow{4}{*}{$\mathrm{MB}_{\mathrm{EVA}}$} & 1 & 528.55 & 0.1134 & 3280 & 1057.1 & 0.3963 & 1.812 & 0.519 & 28.881 \\
\hline & 2 & 550.45 & 0.1163 & 3291 & 1100.9 & 0.4012 & 1.878 & 0.514 & 29.539 \\
\hline & 3 & 459.65 & 0.1108 & 2999 & 919.3 & 0.4016 & 1.576 & 0.532 & 26.269 \\
\hline & Mean & & & 3190 & 1025.77 & 0.3997 & & & 28.23 \\
\hline
\end{tabular}


Table 7. SCB test results at $0^{\circ} \mathrm{C}$ and $-10^{\circ} \mathrm{C}$

\begin{tabular}{|c|c|c|c|c|c|c|c|c|c|}
\hline \multicolumn{10}{|c|}{$-20^{\circ} \mathrm{C}$} \\
\hline Mixture type & Sample No: & $\begin{array}{c}\mathbf{P}_{\mathbf{i}} \\
{[\mathrm{N}]}\end{array}$ & $\begin{array}{c}\delta_{i} \\
{[\%]}\end{array}$ & $\begin{array}{c}\mathbf{E} \\
{\left[\mathrm{N} / \mathrm{mm}^{2}\right]}\end{array}$ & $\begin{array}{l}\mathbf{P}_{\max } \\
{[\mathrm{N}]}\end{array}$ & $\begin{array}{l}\delta_{\text {mak }} \\
{[\%]}\end{array}$ & $\begin{array}{c}\sigma_{\mathrm{Nx}} \\
{[\mathrm{MPa}]}\end{array}$ & $\alpha_{e}$ & $\begin{array}{c}\mathbf{K}_{\mathrm{IC}} \\
{\left[\mathrm{N} / \mathrm{mm}^{3 / 2}\right]}\end{array}$ \\
\hline \multirow{4}{*}{ Neat } & 1 & 764 & 0.1152 & 4406 & 1528 & 0.3855 & 2.619 & 0.497 & 38.843 \\
\hline & 2 & 743.75 & 0.1059 & 4674 & 1487.5 & 0.3922 & 2.545 & 0.52 & 40.653 \\
\hline & 3 & 715.55 & 0.1127 & 4243 & 1431.1 & 0.3892 & 2.446 & 0.506 & 37.366 \\
\hline & Mean & & & 4441 & 1482.2 & 0.389 & & & 38.954 \\
\hline \multirow{4}{*}{$\mathrm{MB}_{\text {SBS-D }}$} & 1 & 737.25 & 0.1153 & 4266 & 1474.5 & 0.398 & 2.528 & 0.505 & 38.432 \\
\hline & 2 & 727.8 & 0.1058 & 4597 & 1455.6 & 0.3961 & 2.495 & 0.523 & 40.225 \\
\hline & 3 & 771.2 & 0.1048 & 4871 & 1542.4 & 0.3826 & 2.639 & 0.516 & 41.566 \\
\hline & Mean & & & 4578 & 1490.83 & 0.3922 & & & 40.075 \\
\hline \multirow{4}{*}{$\mathrm{MB}_{\mathrm{SBS}-\mathrm{M}}$} & 1 & 733.35 & 0.1061 & 4606 & 1466.7 & 0.3863 & 2.509 & 0.517 & 39.642 \\
\hline & 2 & 764 & 0.1179 & 4281 & 1528 & 0.3998 & 2.607 & 0.5 & 39.039 \\
\hline & 3 & 770.6 & 0.1141 & 4465 & 1541.2 & 0.3932 & 2.635 & 0.503 & 39.868 \\
\hline & Mean & & & 4451 & 1511.97 & 0.3931 & & & 39.516 \\
\hline \multirow{4}{*}{$\mathrm{MB}_{\mathrm{EVA}}$} & 1 & 611.3 & 0.1161 & 3608 & 1222.6 & 0.3855 & 2.092 & 0.502 & 31.59 \\
\hline & 2 & 639.55 & 0.1038 & 4199 & 1279.1 & 0.3872 & 2.193 & 0.526 & 35.754 \\
\hline & 3 & 562.95 & 0.0946 & 4129 & 1125.9 & 0.3873 & 1.925 & 0.549 & 34.033 \\
\hline & Mean & & & 3978 & 1209.2 & 0.3867 & & & 33.792 \\
\hline
\end{tabular}

\subsection{Comparison of experimental procedures of fracture mechanics}

Fracture mechanics tests were performed in the scope of the study on both semi-circular and rectangular prism shaped samples using the principles of fracture mechanics. In both experiments, fracture toughness values were calculated at different temperatures. SE(B) test results are given in Table 5, 6 and 7. SCB test results are given in Table 8, 9 and 10. In order to elucidate the linear relationship and its strength between

Table 8. SCB test results at $-20^{\circ} \mathrm{C}$

\begin{tabular}{|c|c|c|c|c|c|}
\hline \multicolumn{6}{|c|}{$0^{\circ} \mathrm{C}$} \\
\hline Mixture type & Sample No: & $\mathrm{F}_{\max }[\mathrm{N}]$ & $\varepsilon_{\max }[\%]$ & $\sigma_{\max }\left[\mathrm{N} / \mathrm{mm}^{2}\right]$ & $\mathrm{K}_{\mathrm{IC}}\left[\mathrm{N} / \mathrm{mm}^{3 / 2}\right]$ \\
\hline \multirow{4}{*}{ Neat } & 1 & 5546.6 & 1.258 & 3.1506 & 18.765 \\
\hline & 2 & 5252.3 & 1.226 & 2.9656 & 17.663 \\
\hline & 3 & 5305.2 & 1.230 & 2.9837 & 17.771 \\
\hline & Mean & 5368.0 & 1.238 & 3.033 & 18.066 \\
\hline \multirow{4}{*}{$\mathrm{MB}_{\text {SBS-D }}$} & 1 & 5243.4 & 1.253 & 2.9883 & 17.799 \\
\hline & 2 & 5628.0 & 1.092 & 3.1694 & 18.877 \\
\hline & 3 & 5401.4 & 1.210 & 3.0620 & 18.237 \\
\hline & Mean & 5424.3 & 1.185 & 3.073 & 18.304 \\
\hline \multirow{4}{*}{$\mathrm{MB}_{\mathrm{SBS}-\mathrm{M}}$} & 1 & 5124.7 & 1.332 & 2.8689 & 17.087 \\
\hline & 2 & 5211.9 & 1.150 & 2.9215 & 17.401 \\
\hline & 3 & 5352.3 & 1.308 & 3.0181 & 17.976 \\
\hline & Mean & 5229.7 & 1.263 & 2.936 & 17.488 \\
\hline \multirow{4}{*}{$\mathrm{MB}_{\mathrm{EVA}}$} & 1 & 4606.5 & 1.039 & 2.5704 & 15.309 \\
\hline & 2 & 4219.9 & 1.056 & 2.3655 & 14.089 \\
\hline & 3 & 4166.3 & 1.069 & 2.3509 & 14.002 \\
\hline & Mean & 4330.9 & 1.055 & 2.429 & 14.467 \\
\hline
\end{tabular}


Table 9. SCB test results at $-10^{\circ} \mathrm{C}$

\begin{tabular}{|c|c|c|c|c|c|}
\hline \multicolumn{6}{|c|}{$-10^{\circ} \mathrm{C}$} \\
\hline Mixture type & Sample No: & $\mathrm{F}_{\max }[\mathrm{N}]$ & $\varepsilon_{\max }[\%]$ & $\sigma_{\max }\left[\mathrm{N} / \mathrm{mm}^{2}\right]$ & $\mathrm{K}_{\mathrm{IC}}\left[\mathrm{N} / \mathrm{mm}^{3 / 2}\right]$ \\
\hline \multirow{4}{*}{ Neat } & 1 & 6696.3 & 1.067 & 3.7685 & 22.445 \\
\hline & 2 & 6625.7 & 1.112 & 3.7411 & 22.282 \\
\hline & 3 & 6497.2 & 1.082 & 3.6758 & 21.893 \\
\hline & Mean & 6606.4 & 1.087 & 3.728 & 22.207 \\
\hline \multirow{4}{*}{$M_{\text {SBS-D }}$} & 1 & 6488.7 & 1.181 & 3.6808 & 21.923 \\
\hline & 2 & 6437.7 & 1.119 & 3.6422 & 21.693 \\
\hline & 3 & 6335.3 & 1.137 & 3.5914 & 21.390 \\
\hline & Mean & 6420.6 & 1.145 & 3.638 & 21.669 \\
\hline \multirow{4}{*}{$\mathrm{MB}_{\mathrm{SBS}-\mathrm{M}}$} & 1 & 7040.1 & 1.061 & 3.9542 & 23.551 \\
\hline & 2 & 6866.3 & 1.157 & 3.8591 & 22.985 \\
\hline & 3 & 7100.5 & 1.091 & 3.9960 & 23.800 \\
\hline & Mean & 7002.3 & 1.103 & 3.936 & 23.445 \\
\hline \multirow{4}{*}{$\mathrm{MB}_{\mathrm{EVA}}$} & 1 & 5920.3 & 0.990 & 3.3406 & 19.897 \\
\hline & 2 & 5752.6 & 0.978 & 3.2503 & 19.359 \\
\hline & 3 & 6083.2 & 1.027 & 3.4280 & 20.417 \\
\hline & Mean & 5918.7 & 0.998 & 3.340 & 19.891 \\
\hline
\end{tabular}

Table 10. SCB test results at $-20^{\circ} \mathrm{C}$

\begin{tabular}{|c|c|c|c|c|c|}
\hline & & $-20^{\circ} \mathrm{C}$ & & & \\
\hline Mixture type & Sample No: & $\mathrm{F}_{\max }[\mathrm{N}]$ & $\varepsilon_{\max }[\%]$ & $\sigma_{\max }\left[\mathrm{N} / \mathrm{mm}^{2}\right]$ & $\mathrm{K}_{\mathrm{IC}}\left[\mathrm{N} / \mathrm{mm}^{3 / 2}\right]$ \\
\hline \multirow{4}{*}{ Neat } & 1 & 6630.6 & 1.031 & 3.7414 & 22.284 \\
\hline & 2 & 7157.4 & 0.979 & 4.0494 & 24.118 \\
\hline & 3 & 6813.0 & 0.954 & 3.8418 & 22.882 \\
\hline & Mean & 6867.0 & 0.988 & 3.878 & 23.094 \\
\hline \multirow{4}{*}{$\mathrm{MB}_{\mathrm{SBS}-\mathrm{D}}$} & 1 & 7145.0 & 1.011 & 4.0504 & 24.124 \\
\hline & 2 & 7017.1 & 1.076 & 3.9516 & 23.536 \\
\hline & 3 & 6890.5 & 1.019 & 3.8676 & 23.035 \\
\hline & Mean & 7017.6 & 1.035 & 3.957 & 23.565 \\
\hline \multirow{4}{*}{$\mathrm{MB}_{\text {SBS-M }}$} & 1 & 7237.9 & 1.056 & 4.0706 & 24.245 \\
\hline & 2 & 6869.3 & 0.995 & 3.8355 & 22.844 \\
\hline & 3 & 7263.3 & 1.090 & 4.0635 & 24.202 \\
\hline & Mean & 7123.5 & 1.047 & 3.990 & 23.764 \\
\hline \multirow{4}{*}{$\mathrm{MB}_{\mathrm{EVA}}$} & 1 & 6144.0 & 0.910 & 3.4622 & 20.621 \\
\hline & 2 & 6171.0 & 0.963 & 3.4614 & 20.616 \\
\hline & 3 & 6090.0 & 0.918 & 3.4183 & 20.359 \\
\hline & Mean & 6135.0 & 0.930 & 3.447 & 20.532 \\
\hline
\end{tabular}

the values, determination coefficients and $\mathrm{K}_{\mathrm{IC}}$ values equations for all mixtures were identified at the same temperature. Mean $\mathrm{K}_{\mathrm{Ic}}$ values were used in the assessment. The determination coefficients and equations are given in Figure 9.

The values displayed in Figure 9 were determined by Microsoft Excel linear regression analyses. Analysis results demonstrate that $R^{2}$ values are extremely high. The lowest value was identified at $0{ }^{\circ} \mathrm{C}(0.8641)$ and the value increased with the decrease in temperature. It was revealed by analysis results that $\mathrm{K}_{\mathrm{IC}}$ values for SCB samples could be explained by $\mathrm{K}_{\mathrm{IC}}$ values of $\mathrm{SE}(\mathrm{B})$ samples at the rate of $86.41 \%$ and at $0{ }^{\circ} \mathrm{C}$, whereas the same rate was $88.07 \%$ and $98.06 \%$ at -10 and $-20{ }^{\circ} \mathrm{C}$, respectively. 


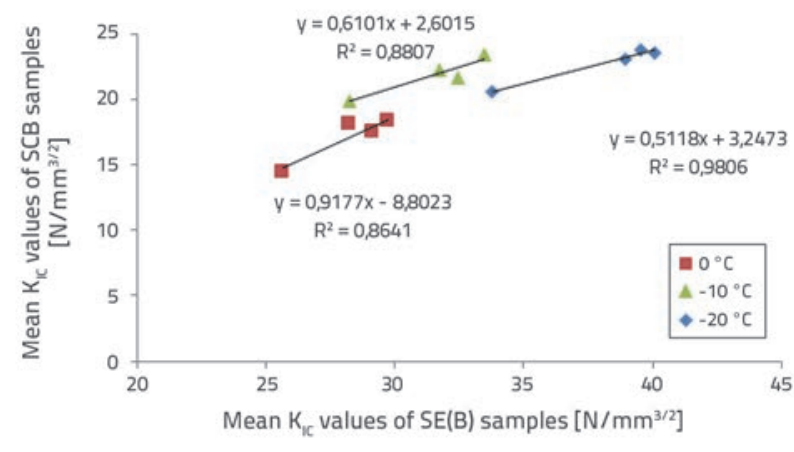

Figure 9. Linear regression parameters of $\mathrm{K}_{\mathrm{Ic}}$ values

Correlation coefficients ( $r$ ) for $\mathrm{K}_{\mathrm{IC}}$ values obtained from SCB and $\mathrm{SE}(\mathrm{B})$ samples at $\mathrm{O}^{\circ} \mathrm{C},-10^{\circ} \mathrm{C}$ and $-20^{\circ} \mathrm{C}$ were calculated. It was determined that these correlation coefficient values were 0.930 , 0.938 and 0.990 , respectively. These values demonstrated a positive correlation between $K_{\mathrm{lc}}$ values. Furthermore, the analysis of correlation strength demonstrated that $r$ values were greater than 0.90 at all three temperatures $\left(0^{\circ} \mathrm{C},-10^{\circ} \mathrm{C}\right.$ and $-20^{\circ} \mathrm{C}$ ). Therefore, there was a strong correlation between the results obtained with both experimental methods. Furthermore, it was identified that the strength of this correlation increased with the decrease in temperature.

\section{Conclusions}

The low-temperature crack propagation resistance of control and polymer modified mixtures was examined in this study using two distinct experimental techniques. Within this scope, the design of binder and mixture was conducted using the Superpave method.

According to semi-circular bending tests performed, fracture toughness values increased with the decrease in temperature, while the maximum vertical strain values decreased. At all temperatures, the lowest $\mathrm{K}_{\mathrm{IC}}$ value was obtained in $\mathrm{MB}_{\mathrm{EVA}}$. The highest value, on the other hand, was obtained in $\mathrm{MB}_{\mathrm{SBS}-\mathrm{D}}$ at 0 ${ }^{\circ} \mathrm{C}$ and $\mathrm{MB}_{\mathrm{SBS}-\mathrm{M}}$ at $-10^{\circ} \mathrm{C}$ and $-20^{\circ} \mathrm{C}$.

Single edge notched beam experiments revealed that fracture toughness values based on ECM increase, while the maximum vertical deformation value decreases with the decrease in temperature. At all temperatures, the lowest $K_{1 C}$ value was obtained in $\mathrm{MB}_{\mathrm{EVA}}$. The highest value, on the other hand, was obtained in $\mathrm{MB}_{\mathrm{SBS}-\mathrm{D}}$ at $0{ }^{\circ} \mathrm{C}$ and $-20^{\circ} \mathrm{C}, \mathrm{MB}_{\mathrm{SBS}-\mathrm{M}}$ at $-10^{\circ} \mathrm{C}$.

When the effects of binders are compared, the experiments show that the low-temperature performance of $\mathrm{MB}_{\mathrm{SBS}-\mathrm{D}}$ and $\mathrm{MB}_{\mathrm{SBS}-\mathrm{M}}$ is higher compared to $\mathrm{MB}_{\mathrm{EVA}}$. The experiments in which mixtures were compared with each other showed that, at low temperature, the resistance to crack propagation increases with the addition of SBS type elastomers to pure mixtures. For EVA type plastomers, the resistance is lost to some extent. When the experimental procedures are compared, it can be stated that two techniques are coherent and approximately linear to one another.

\section{Acknowledgements}

This study was supported by Fırat University Scientific Research Projects Unit (FUBAP) under project number MF.12.01. The financial contribution of FUBAP is gratefully acknowledged.

\section{REFERENCES}

[1] Hribar, D., Tušar, M.: Properties of Asphalt Concrete at Low Temperatures, Građevinar, 64 (2012) 10, pp. 825-831.

[2] Hribar, D., Tušar, M., Hofko, B., Blab, R.: Influence of Start Temperature on Tensile Stress Testing of Restrained Asphalt Concrete Specimens, Građevinar, 65 (2013) 11, pp. 987-992.

[3] Ma, H., Wang, D., Zhou, C., Feng, D.: Calibration on MEPDG Low Temperature Cracking Model and Recommendation on Asphalt Pavement Structures in Seasonal Frozen Region of China, Advances in Materials Science and Engineering, Volume 2015, Article ID 830426, 11 pages, 2015.

[4] Das, P.K., Tașdemir, Y., Birgisson, B.: Low Temperature Cracking Performance of WMA with the Use of the Superpave Indirect Tensile Test, Construction and Building Materials, 30 (2012), pp. 643-649, https://doi.org/10.1016/j.conbuildmat.2011.12.013

[5] Isacsson, U., Zeng, H.: Relationships Between Bitumen Chemistry and Low Temperature Behaviour of Asphalt, Construction and Building Materials, 11 (1997) 2, pp. 83-91, https://doi.org/10.1016/ S0950-0618(97)00008-1
[6] Polacco, G., Kriz, P., Filippi, S., Stastna, J., Biondi, D., Zanzotto, L.: Rheological Properties of Asphalt/SBS/Clay Blends, Europan Polymer Journal, 44 (2008) 11, pp. 3512-3521, https://doi. org/10.1016/j.eurpolymj.2008.08.032

[7] Sureshkumar, M.S., Filippi, S., Polacco, G., Kazatchkov, I., Stastna, J., Zanzotto, L.: Internal Structure and Linear Viscoelastic Properties of EVA/Asphalt Nanocomposites, Europan Polymer Journal, 46 (2010), pp. 621-633, https://doi.org/10.1016/j. eurpolymj.2009.12.024

[8] Yilmaz, M., Yalcin, E.: The Effects of Using Different Bitumen Modifiers and Hydrated Lime together on the Properties of Hot Mix Asphalts, Road Materials and Pavement Design, 17 (2016) 2, https://doi.org/10.1080/14680629.2015.1091376

[9] Airey, G.: Rheological Evaluation of Ethylene Vinyl Acetate Polymer Modified Bitumens, Construction and Building Materials, 16 (2002) 8, pp. 473-487, https://doi.org/10.1016/S0950-0618(02)001034 
[10] Sengoz, B., Isıkyakar, G.: Evaluation of the Properties and Microstructure of SBS and EVA Polymer Modified Bitumen, Construction and Building Materials, 22 (2008) 9, pp. 1897-1905, https://doi.org/10.1016/j.conbuildmat.2007.07.013

[11] Singh, M., Kumar, P., Anupam, A.K.: Affect of Type of Aggregate on Permanent Deformation of Bituminous Concrete Mixes, Road Materials and Pavement Design, https://doi.org/10.1080/1468062 9.2015 .1091374

[12] Topal, A.: Evaluation of the Properties and Microstructure of Plastomeric Polymer Modified Bitumens, Fuel Processing Technology, 91 (2010), pp. 45-51, https://doi.org/10.1016/j. fuproc.2009.08.007

[13] Doğan, M.: Effect of Polymer Additives on the Physical Properties of Bitumen Based Composites, Ankara, M.Sc. Thesis, Graduate School of Natural and Applied Sciences, Middle East Technical University, 2006.

[14] Airey, G.: Rheological Properties of Styrene Butadiene Styrene Polymer Modified Road Bitumens, Fuel, 82 (2003) 14, pp. 17091719, https://doi.org/10.1016/S0016-2361(03)00146-7

[15] Scholten, E.J., Vonk, W., Korenstra, J.: Towards Green Pavements with Novel Class of SBS Polymers for Enhanced Effectiveness in Bitumen and Pavement Performance, International Journal of Pavement Research and Technology, 3 (2010) 4, pp. 216-222.

[16] Vonk, W., Scholten, E.J., Korenstra, J.: Novel Class of SBS Polymers for Enhanced Effectiveness in Bitumen Modification, Australian Asphalt Paving Association Thirteenth International Flexible Pavements Conference, Queensland, Australia, 2010.

[17] Molenaar, J.M.M.: Performance Related Characterization of the Mechanical Behaviour of Asphalt Mixtures, Rijkswaterstaat Road and Hydraulic Engineering Institute, Delfth, Netherlands, 2003.
[18] Kim, K.W., Hussein, M.E.: Variation of Fracture Toughness of Asphalt Concrete Under Low Temperatures, Construction and Building Materials, 11 (1997) 8, pp. 403-411, https://doi. org/10.1016/S0950-0618(97)00030-5

[19] Lu, X., Isacsson, U.: Rheological Characterization of StyreneButadiene-Styrene Copolymer Modified Bitumens, Construction and Building Materials, 11 (1997) 1, pp. 23-32, https:/doi. org/10.1016/S0950-0618(96)00033-5

[20] Zaniewski, J.P., Pumphrey, M.E.: Evaluation of Performance Graded Asphalt Binder Equipment And Testing Protocol, Asphalt Technology Program, 2004.

[21] Mc Gennis, R.B., Shuler, S., Bahia, H.U.: Background of Superpave Asphalt Binder Test Methods, Report No: FHWA-SA-94-069, 1994.

[22] EN 12697-44: Bituminous Mixtures - Test Methods for Hot Mix Asphalt - Part 44, Crack Propagation by Semi-Circular Bending Test, European Standard, 2010.

[23] Wagoner, M.P., Buttlar, W.G., Paulino, G.H.: Development of a Single-Edge Notched Beam Test for Asphalt Concrete Mixtures, Journal of Testing and Evaluation, 33 (2005) 6, pp. 1-9.

[24] Marasteanu, M., Falchetto, A.C., Moon, K.H.: Investigation of Low Temperature Cracking in Asphalt Pavements, National Pooled Fund Study - Phase II, 2009.

[25] Wagoner, M.P., Buttlar, W.G., Paulino, G.H.: Disk-Shaped Compact Tension Test for Asphalt Concrete Fracture, Experimental Mechanics, 45 (2005) 3, pp. 270-277, https://doi. org/10.1177/0014485105053205

[26] Karihaloo, B.L., Nallathambi, P.: Notched Beam Test: Mode-I Fracture Toughness, In Fracture Mechanics Test Methods for Concrete, Report of Technical Committee 89-FMT, RILEM, 1991. 